\title{
QUALIFICATION METHODS FOR ASSESSMENT OF ANNOYANCE OF IMPULSIVE SOUNDS
}

\begin{abstract}
This paper presents the work on the problem of the qualification of impulsive sounds for applying the adequate value of impulsive adjustment. Impulsive events must be included in the assessment of noise in Poland. There is no agreement for using the objective methods that could qualify impulsive sounds on the basis of the measurable physical characteristics of the impulses. Moreover, the arbitrary classification includes only a few specified sources. The paper presents a review of the methods and criteria for the qualification of the impulses and provides the results of applying these methods on a certain impulsive noise source - the collision of train cars.
\end{abstract}

Keywords: impulsive noise, impulsive adjustment, noise annoyance

\section{METODY KWALIFIKACJI DŹWIĘKÓW IMPULSOWYCH POD WZGLĘDEM OCENY ICH UCIĄŻLIWOŚCI}

$W$ artykule zaprezentowano problem kwalifikacji dźwięków impulsowych $w$ aspekcie wyznaczenia odpowiedniej wartości poprawki impulsowej. Uwzględnianie zjawisk impulsowych $w$ ocenie hałasu środowiskowego jest w Polsce obowiązowe. Jednakże nie ma jednej obiektywnej metody kwalifikacji impulsów na podstawie ich mierzalnych cech fizycznych. Co więcej, stosowane arbitralne metody obejmują jedynie kilka przypadków. W artykule dokonano przegladu obowiazujących metod i kryteriów kwalifikacji dźwięków impulsowych, a także dokonano weryfikacji tych metod na przykładzie wybranego dźwięku impulsowego - zderzeń wagonów.

Stowa kluczowe: hałas impulsowy, korekcja impulsowa, uciążliwość hałasu

\section{INTRODUCTION}

The major problem in the objective evaluation of impulsive events is the subjective reaction caused by exposure to noise. This problem is particularly relevant when the noise sources are generally considered as burdensome.

Assessment of the environmental noise based on the A-weighted equivalent sound pressure level is commonly used for general cases, but it is insufficient for assessing the noise sources with a high annoyed content; i.e., tonality, low-frequency components, large variability in time, and impulsiveness. For the last group, a lot of difficulties can occur with assessing high impulsive sounds, especially for those not covered by legal and normative acts regulating the problem of annoyance with impulsive noise.

This paper presents the current state of knowledge about the commonly used criteria and methods of qualification of impulsive sounds in order to assess their annoyance, which can be used as a support for proposing an adequate value of impulsive adjustment. An evaluation of the usefulness of indicators was performed with the proposal of new descriptors based on the spectral analysis of the impulsive signals.

\section{ASSESSMENT OF IMPULSIVE NOISE}

The two main features of an impulsive sound are: a very short duration, usually less than one second (ISO 1996 1:2003, ISO 1996-2:2007) and a high value of the peak sound pressure level (Henderson and Hamernik 1986,
Hamernik and Hsueh 1991, ISO 1996-1:2003). These features considered as the basis for identifying the impulses do not allow us to classify these sounds unambiguously in terms of their harmful effects on humans or on the feeling of an acoustic annoyance (Wszołek 2015).

The fundamental measure of the assessment of noise in Poland according to legal documents (Environmental Protection Law 2001, Regulation of Minister of Environment 2014) is equivalent sound pressure level $L_{\text {AeqT }}$, and as an additional measure, A-weighted sound exposure level $L_{A E}$, which is usually used for the evaluation of single acoustics events, including impulses. Definitions of these levels are given in the standard (ISO 1996-1:2003). This standard also provides the possibility of level adjustment depending on certain characteristics of the sound, source type, or time of its occurrence so that the final value shall be adequate for their annoyance.

If necessary, the A-weighted equivalent sound pressure level and A-weighted sound exposure level need to be corrected with the relevant adjustment. These modified levels are called rating levels; given in Equations (1) and (2).

$$
L_{R E i j}=L_{A E i j}+K_{j}[\mathrm{~dB}]
$$

$$
L_{\mathrm{Re} q j, T n}=L_{\text {Aeqj }, T n}+K_{j}[\mathrm{~dB}]
$$

where:

$i$ - number of impulsive acoustic event,

$j$ - sound source type,

$K j$ - adjustment for $j$-th type of source (ISO 1996-1:2003).

\footnotetext{
* AGH University of Science and Technology, Faculty of Mechanical Engineering and Robotics, Department of Mechanics and
} Vibroacoustics, Krakow, Poland; e-mail:kukulski@agh.edu.pl 
For assessment of the impulse noise from a measurement point of view, two cases can be considered (PN-ISO 1996-2:1999/A1:2002):

1) Single impulsive sounds (events) are easy to identify, and they can be independently measured as single acoustic events. Adjustment $K j$ is applied only to the sound exposure level.

2) In a given period of time, it is not possible to measure independent acoustic events. Standard (ISO 1996-1:2003) allows the use of both adjustments given in Equation (1) as well as (2) with the limitation that only the equivalent sound pressure level for the time of occurrence of impulses should be adjusted.

The adjustment value for impulse noise varies between 5 and $12 \mathrm{~dB}$ depending on the category to the source of these sounds. As indicated at the beginning of this paper, such a classification is strongly arbitrary and is a compromise based heavily on a subjective assessment of these signals and only slightly of its physical characteristics.

In the evaluation of impulsive noise with adjustments, three general categories of sources of impulse noise can be distinguished: high-energy impulsive (e.g., artillery, explosions in mines, sound blasts), highly impulsive (e.g., pneumatic hammer, gunshots), and regular impulsive; that is, for all other impulsive sounds that cannot be assigned to either of the first two categories (e.g., a car door slamming, church bells). Adjustment should be applied only when the impulsive sound source is clearly audible at the measuring point. However, there is a lack of both quantitative and qualitative criteria to qualify the source as a clearly audible.

Table 1 contains the typical values of impulsive adjustments related to the source type. Methods for determining the adjustment for high-energy impulsive noise are described later in the paper.

Table 1

Typical level adjustments based on impulsive sound source character

\begin{tabular}{|c|c|}
\hline Source character & Level adjustment [dB] \\
\hline Regular impulsive & 5 \\
\hline Highly impulsive & 12 \\
\hline High-energy impulsive & Level-dependent \\
\hline
\end{tabular}

For the first two categories of impulsive sound sources, the adjustment value is constant; the problem could be the unambiguous qualification of impulse to one of the categories (a subjective criterion) as well as the identification of the intervals in which the impulses occur (an objective criterion).
For high-energy impulsive sound sources, the calculation of an adequate value of adjustment is based on C-weighted sound exposure level $L_{C E}$. Rating sound exposure level $L_{R E}$ can be determined in two ways depending on the value of the level of $L_{C E}$.

$$
\begin{aligned}
& L_{R E}=2 L_{C E}-93[\mathrm{~dB}] \quad \text { for } \quad L_{C E} \geq 100 \mathrm{~dB} \\
& L_{R E}=1.18 L_{C E}-11[\mathrm{~dB}] \quad \text { for } \quad L_{C E}<100 \mathrm{~dB}
\end{aligned}
$$

The literature provides two alternative models for evaluating rating levels, both developed on empirical studies different types of gunfire sounds. The first model (Miedema 2004, ISO 1996-1:2003) is based on the difference between maximum levels $L_{C F \max }$ and $L_{A F \max }$ in conjunction with sound exposure level $L_{C E}$ :

$$
L_{R E}=1.4 L_{C E}-0.92\left(L_{C F \max }-L_{A F \max }\right)-21.9[\mathrm{~dB}]
$$

The second model, (Berry and Bispring 1988) is based on the difference between sound exposure levels $L_{C E}$ and $L_{A E}$ in conjunction with A-weighted sound exposure level $L_{A E}$ :

$$
L_{R E}=L_{A E}+12+0.015\left(L_{C E}-L_{A E}\right)\left(L_{A E}-47\right)[\mathrm{dB}](6)
$$

\section{IMPULSIVE NOISE SOURCE QUALIFICATION}

The selection of the appropriate value of impulsive adjustment should be preceded by the recognition of the impulsive sound source. Throughout the years, a number of criteria for qualification and classification has been provided in the literature.

In a survey conducted in the 80s and 90s (CHABA 1981, 1996), it was proposed that the fundamental indicator for the identification and qualification of signals as impulsive shall be the $\mathrm{C}$-weighted sound exposure level whose value should be equal to or greater than $85 \mathrm{~dB}$ during the day or $75 \mathrm{~dB}$ at night.

Another proposed criterion is the difference between A-weighted peak sound pressure level $L_{\text {Apeak }}$ and A-weighted RMS sound pressure level measured with time constant SLOW, $L_{A S}$. This difference is called impulsiveness $I$. When the value of impulsiveness is greater or equal to the threshold value, the signal is treated as an impulse.

$$
I=L_{\text {Apeak }}-L_{A S} \geq 15 \mathrm{~dB}
$$

Additionally, two more dependencies can be distinguished in the process of qualification. These are (respectively): the difference in $\mathrm{C}$-weighted and A-weighted sound exposure levels $L_{C E}-L_{A E}$, and measure of the 
increase in sound pressure level during the impulse duration:

$$
\Delta L=L_{A \max }-L_{A t}[\mathrm{~dB}]
$$

where:

$L_{A \max }-A$-weighted maximum sound pressure level, $L_{A t}-$ A-weighted sound pressure level.

Qualification of impulsive signals can also be carried out on the basis of the physical parameters of these sounds. For that purpose, the authors propose the following parameters: A-weighted peak sound pressure level, $L_{\text {Apeak }}$, C-weighted peak sound pressure level, $L_{\text {Cpeak }}$, maximum sound pressure levels $L_{A \max }$ and $L_{C \max }$, and (also mentioned at the beginning of the paper) sound exposure levels $L_{A E}$ and $L_{C E}$, as a measure of energy.

The next two parameters that can be used in the qualification of impulsive signals are rise time $t_{R}$ and the steepness (rapidity) of impulse rise $V_{L}$ (Wszołek 2015). The rise time is determined by the time at which the signal value increases from $10 \%$ to $90 \%$ of the maximum absolute value (Henderson and Hamernik 1986, PN-ISO 10843:2002).

All of the mentioned methods of the qualification of impulsive sound are based on single number indicators, that do not include the assessment of impulsive signals spectra in relation to the spectrum of the background noise. The experimental part of the paper focuses on the evaluating selected examples of impulsive noise using predefined metrics and performing a spectral analysis of signals with a proposal of frequency-domain measurable parameters.

\section{EXPERIMENTAL}

Experimental studies consist of the registration and analysis of impulsive noise from collisions of train cars. The preview picture of the measurements is presented in Figure 1.

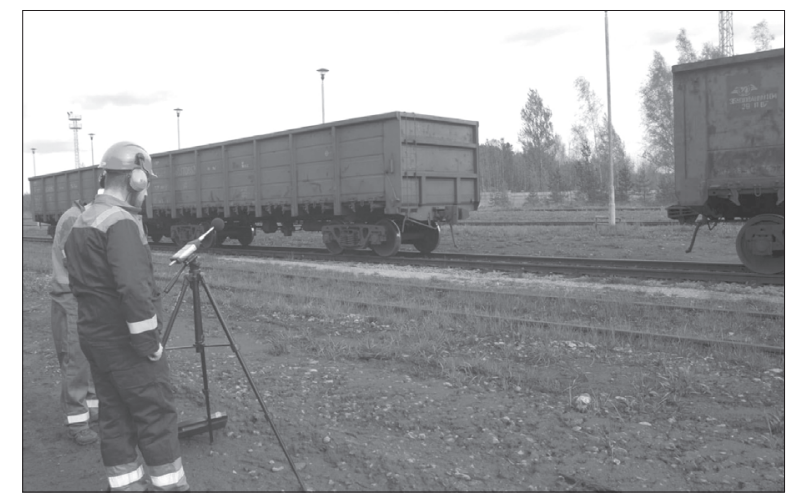

Fig. 1. Registration of the collision of train cars

Measurements were made by using sound-level meters Svan 958, Svan 959, and Svan 979. The signals were recorded with a registration resolution of $50 \mathrm{~ms}$ in $1 / 3$ octave bands from $20 \mathrm{~Hz}$ to $20 \mathrm{kHz}$ with a real limitation in the low frequency range, as a result of the short time recording. Each event was measured simultaneously at three measurement points: 10, 120, and 270 meters from the collision of the train cars.

Figures 2, 3 present a comparison of the waveforms of the sound pressure level: A-weighted and C-weighted of two selected collisions, "strong" (collision No. 5) and "weak" (collision No. 4) for all three measurement points. In practice, the sound emitted is strongly dependent on the speed of the colliding train cars which can be noted from the values.

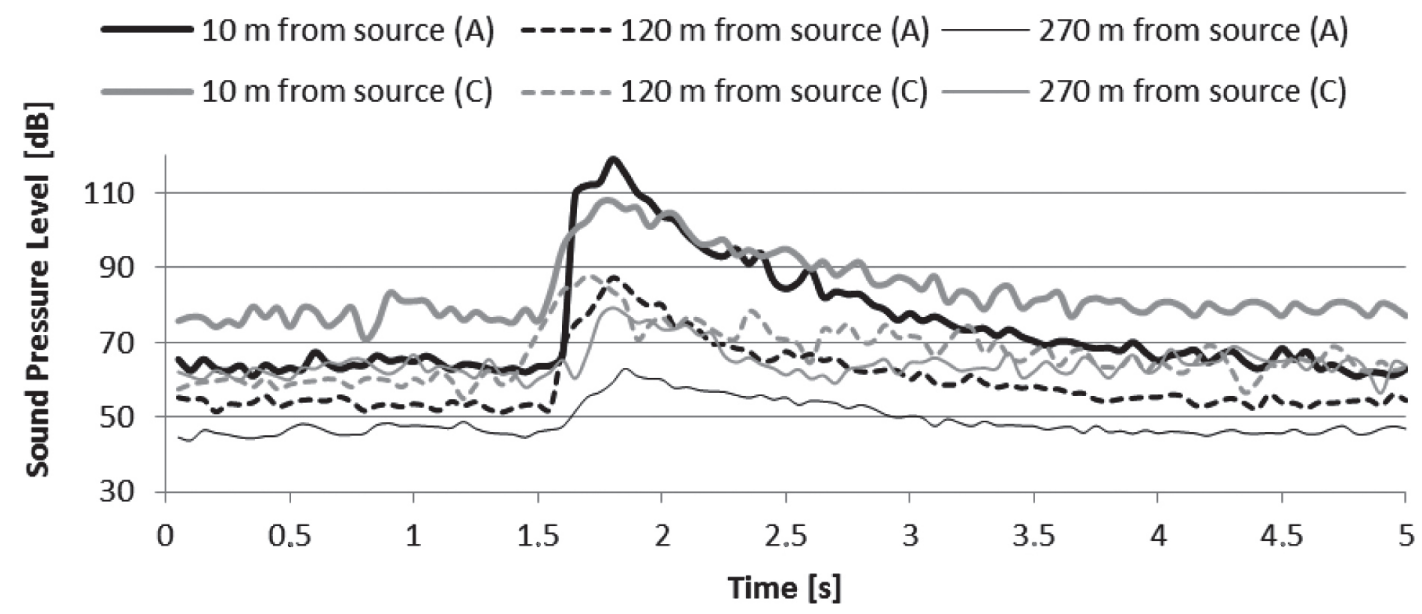

Fig. 2. A-weighted and C-weighted sound pressure levels versus time for "Strong" impulsive collision (No. 5) 


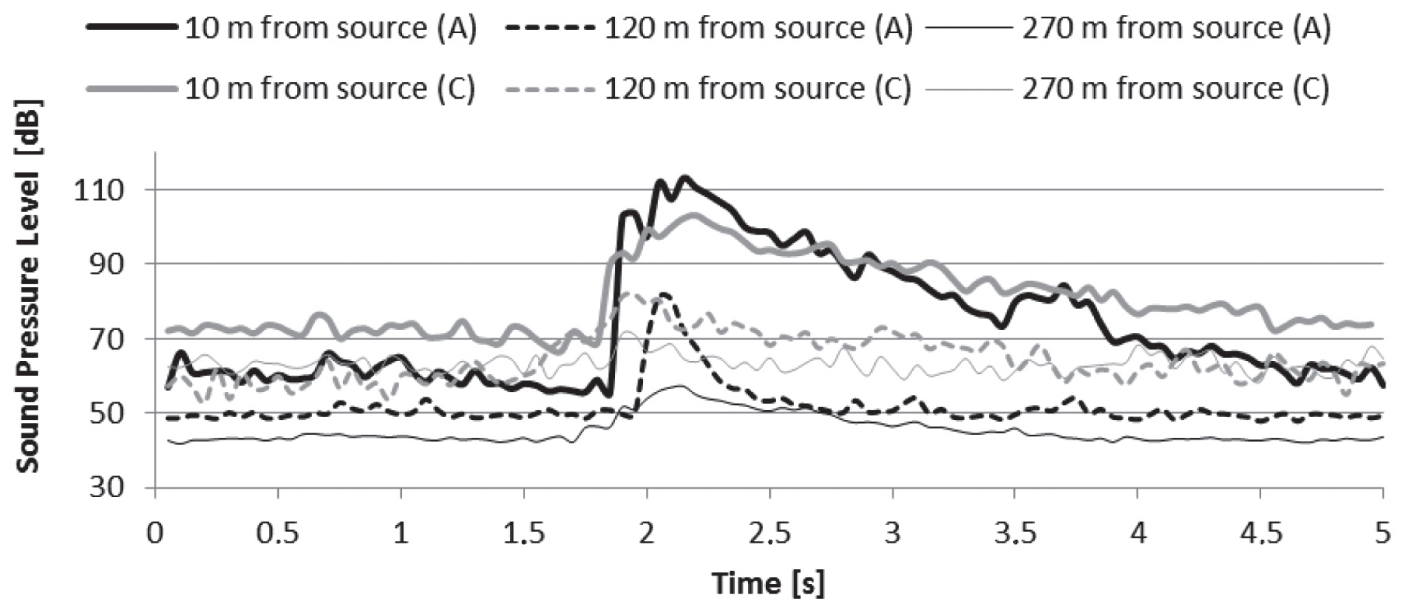

Fig. 3. A-weighted and C-weighted sound pressure levels versus time for "Weak" impulsive collision (No. 4)

Table 2 presents the values of the parameters described terion of treating the event as an impulse; i.e., $L_{C E}$ values in the previous section for the six selected collisions of exceed the threshold of $85 \mathrm{~dB}$. For the signals recorded at the train cars.

All of the signals registered at distances of $10 \mathrm{~m}$ and $120 \mathrm{~m}$ from the source of the collision meet the basic cria distance of $270 \mathrm{~m}$ from the source, this criterion was not met (although the value of this parameter is relatively close to the threshold).

Table 2

Impulse waveform parameters measured in several distances from the source

\begin{tabular}{|c|c|c|c|c|c|c|c|c|c|c|c|c|}
\hline Collision $\mathbf{N}^{0}$ & $\begin{array}{c}\text { Distance } \\
\text { from source } \\
{[\mathrm{m}]}\end{array}$ & $\begin{array}{c}L_{A E} \\
{[\mathrm{~dB}]}\end{array}$ & $\begin{array}{l}L_{C E} \\
{[\mathrm{~dB}]}\end{array}$ & $\begin{array}{c}L_{A \max } \\
{[\mathrm{dB}]}\end{array}$ & $\begin{array}{c}L_{C \max } \\
{[\mathrm{dB}]}\end{array}$ & $\begin{array}{c}L_{\text {Apeak }} \\
{[\mathrm{dB}]}\end{array}$ & $\begin{array}{c}L_{\text {Cpeak }} \\
{[\mathrm{dB}]}\end{array}$ & $\begin{array}{c}L_{C E}-L_{A E} \\
{[\mathrm{~dB}]}\end{array}$ & $\begin{array}{l}\Delta L_{A} \\
{[\mathrm{~dB}]}\end{array}$ & $\begin{array}{c}I_{A} \\
{[\mathbf{d B}]}\end{array}$ & $\begin{array}{l}t_{R A} \\
{[\mathrm{~s}]}\end{array}$ & $\begin{array}{c}V_{L A} \\
{[\mathrm{~dB} / \mathrm{s}]}\end{array}$ \\
\hline \multirow{3}{*}{ Collision 1} & 10 & 100.6 & 104.8 & 105.3 & 107.4 & 119.0 & 118.8 & 4.2 & 53.5 & 33.2 & 0.3 & 163.7 \\
\hline & 120 & 70.8 & 81.7 & 74.4 & 82.8 & 86.3 & 91.7 & 10.9 & 35.2 & 31.9 & 0.4 & 89.7 \\
\hline & 270 & 62.4 & 79.4 & 60.6 & 74.9 & 71.9 & 84.1 & 17.0 & 18.3 & 25.3 & 0.4 & 53.8 \\
\hline \multirow{3}{*}{ Collision 2} & 10 & 96.7 & 101.5 & 102.3 & 104.2 & 117.8 & 116.5 & 4.8 & 57.8 & 37.8 & 0.3 & 166.3 \\
\hline & 120 & 68.9 & 83.6 & 71.0 & 81.5 & 86.7 & 89.5 & 14.7 & 32.8 & 39.3 & 0.4 & 87.5 \\
\hline & 270 & 64.5 & 82.0 & 58.2 & 75.4 & 70.8 & 87.4 & 17.5 & 13.0 & 21.5 & 0.35 & 40.3 \\
\hline \multirow{3}{*}{ Collision 3} & 10 & 100.7 & 105.8 & 106.4 & 109.4 & 120.4 & 122.9 & 5.1 & 61.6 & 34.9 & 0.35 & 167.1 \\
\hline & 120 & 72.6 & 86.0 & 76.0 & 87.1 & 88.0 & 97.5 & 13.4 & 29.4 & 34.9 & 0.35 & 78.0 \\
\hline & 270 & 65.1 & 80.8 & 60.7 & 77.4 & 72.8 & 84.5 & 15.7 & 9.2 & 23.8 & 0.45 & 41.1 \\
\hline \multirow{3}{*}{ Collision 4} & 10 & 94.9 & 98.9 & 99.5 & 101.7 & 113.2 & 113.3 & 4.0 & 57.5 & 34.0 & 0.35 & 182.9 \\
\hline & 120 & 68.0 & 84.7 & 68.7 & 80.1 & 81.2 & 88.8 & 16.7 & 24.9 & 37.3 & 0.4 & 81.5 \\
\hline & 270 & 61.9 & 82.0 & 55.9 & 74.8 & 67.1 & 86.3 & 20.1 & 10.4 & 22.3 & 0.45 & 36.4 \\
\hline \multirow{3}{*}{ Collision 5} & 10 & 98.2 & 102.5 & 104.0 & 106.1 & 119.0 & 117.5 & 4.3 & 36.9 & 37.0 & 0.4 & 174.9 \\
\hline & 120 & 68.3 & 81.9 & 72.5 & 85.8 & 87.3 & 94.6 & 13.6 & 29.2 & 31.8 & 0.3 & 117.0 \\
\hline & 270 & 71.5 & 81.0 & 75.5 & 76.8 & 86.2 & 88.1 & 9.5 & 29.9 & 29.7 & 0.2 & 98.3 \\
\hline \multirow{3}{*}{ Collision 6} & 10 & 98.6 & 102.7 & 104.1 & 106.3 & 119.6 & 119.8 & 4.1 & 57.6 & 36.2 & 0.45 & 168.4 \\
\hline & 120 & 69.3 & 82.1 & 71.9 & 84.4 & 83.1 & 93.5 & 12.8 & 31.2 & 28.3 & 0.45 & 70.7 \\
\hline & 270 & 64.8 & 82.9 & 63.5 & 74.3 & 74.6 & 83.7 & 18.1 & 19.2 & 26.5 & 0.4 & 47.0 \\
\hline
\end{tabular}


The values of the increase in sound level $\Delta L$, the steepness of impulsive sound $V_{L}$, and impulsiveness $I$ decrease with an increase in distance from the source; even at the farthest point of measurement, these parameters denote strong signal impulsiveness. Both for $\Delta L$ and $V_{L}$, the values rapidly decrease with an increase in distance. The difference between the C-weighted and A-weighted sound exposure levels increases with increasing distance from the source (which is understandable according to the stronger attenuation in high frequency bands). Finally, each of the analyzed signals has a short rise time (not exceeding $0.5 \mathrm{~s}$ ) and is not diversified much.

The next step was to determine the rating sound exposure level described in Equations (3)-(6). The following nomenclature is assumed: Model I - Equation (3) and (4); Model II - Equation (5); Model III - Equation (6). Average values of the designated rating sound exposure levels together with the corresponding values of the impulsive adjustment (difference between $L_{R E}$ and $L_{C E}$ ) dependent on the model and the distance from the source are presented in Table 3.
The obtained results demonstrate that the adjustment (and, thus, the rating level) increases with distance from the source for Model I and decreases for Model II, while the results for Model III are similar regardless of the distance from the source. The adjustment values calculated with Model II seem to be the most similar to the subjective feeling of impulsiveness, since the impulsive character loses its character with distance.

Figures 4 and 5 present a comparison of the 1/3 octave band spectra for the two characteristic collisions presented previously in Figures 2 and 3. Both in the case of "strong” and ,weak" collisions, the spectrum loses the characteristic feature for impulsive signals; i.e., a broad spectrum with a similar level in each band. With an increase in distance, the sound level in the bands between $50 \mathrm{~Hz}$ and $2000 \mathrm{~Hz}$ decreases by similar values, while a sharp drop in sound level occurs in the high-frequency bands, which is affected by air absorption (ISO 9613-1:1993) among other things. Additionally, for the event of a "strong” collision, sound levels in the respective bands are about a few dBs higher than for the „weak" collision. However, the overall trend of the spectrum deformation in the way of propagation is similar.

Table 3

Rating Sound Exposure Levels with Impulsive Adjustment in relation with distance from source

\begin{tabular}{|c|c|c|c|c|c|c|}
\cline { 2 - 7 } \multicolumn{1}{c|}{} & \multicolumn{2}{c|}{ Model I } & \multicolumn{2}{c|}{ Model II } & \multicolumn{2}{c|}{ Model III } \\
\hline $\begin{array}{c}\text { Distance } \\
\text { from source } \\
{[\mathbf{m}]}\end{array}$ & $\begin{array}{c}\text { LRE } \\
\text { [dB] }\end{array}$ & $\begin{array}{c}\text { Adjustment } \\
\text { [dB] }\end{array}$ & $\begin{array}{c}\text { LRE } \\
\text { [dB] }\end{array}$ & $\begin{array}{c}\text { Adjustment } \\
\text { [dB] }\end{array}$ & $\begin{array}{c}\text { LRE } \\
\text { [dB] }\end{array}$ & $\begin{array}{c}\text { Adjustment } \\
\text { [dB] }\end{array}$ \\
\hline 10 & 112.6 & 14.3 & 119.8 & 21.5 & 113.7 & 15.4 \\
\hline 120 & 87.3 & 17.7 & 84.5 & 14.8 & 88.7 & 16.6 \\
\hline 270 & 85.0 & 20.0 & 79.8 & 14.8 & 81.3 & 16.3 \\
\hline
\end{tabular}
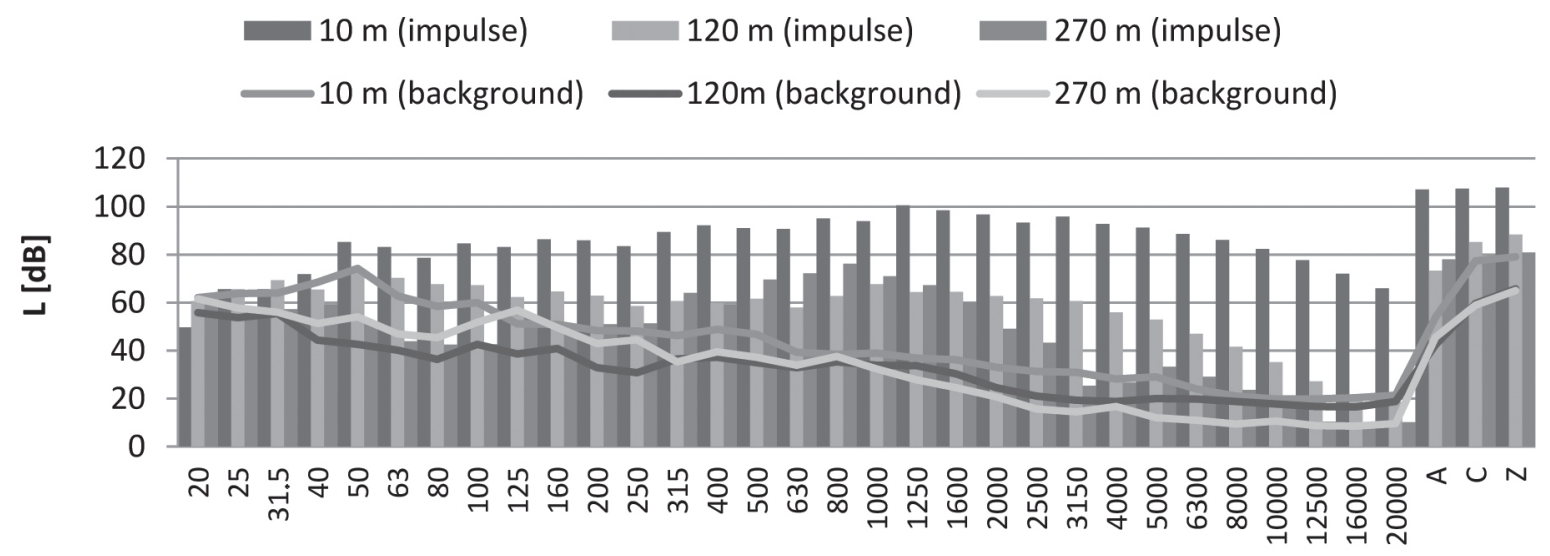

\section{Frequency $[\mathrm{Hz}]$}

Fig. 4. 1/3 octave band spectrum comparison for "Strong" impulsive collision in relation with background noise (No. 5) 


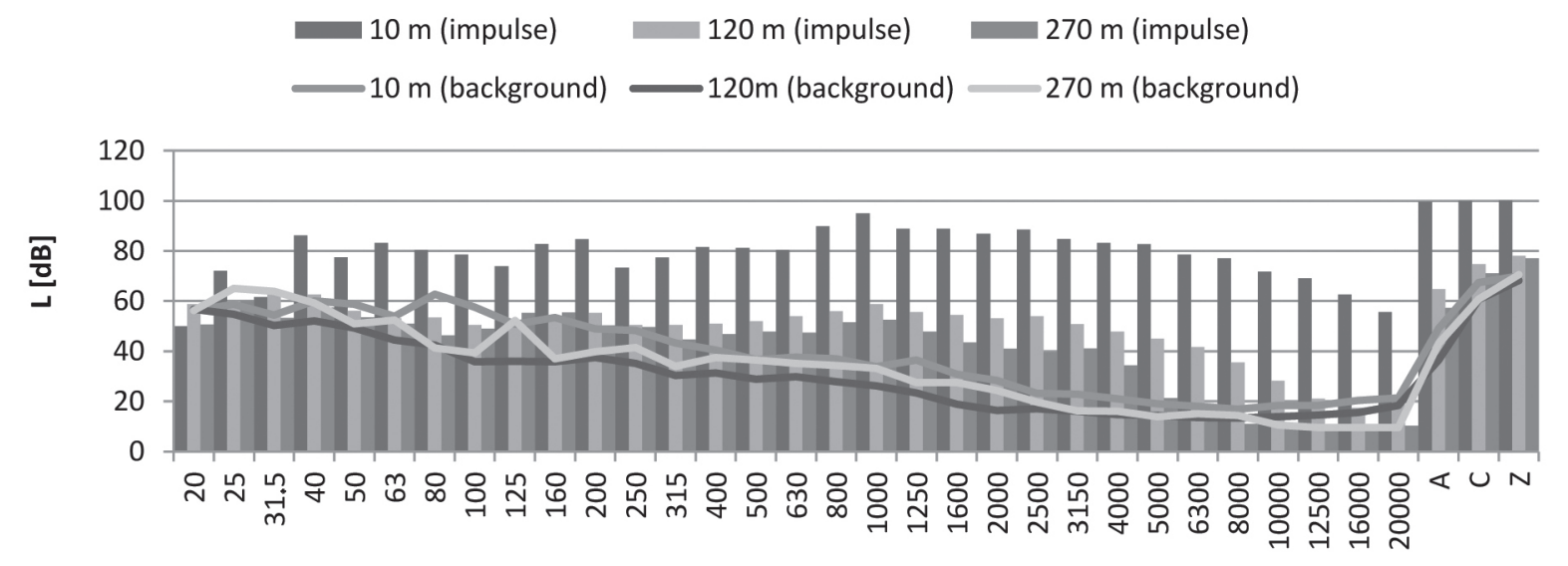

Frequency $[\mathrm{Hz}]$

Fig. 5. 1/3 octave band spectrum comparison for "Weak" impulsive collision in relation with background noise (No. 4)

Evaluating just the changes in the levels of spectrum bands $1 / 3$ octave, depending on the distance from the source gives only general assessment and it can be insufficient. For better qualification and assessment, a set of additional spectrum-dependent descriptors was proposed. The first proposed descriptor is the average spectral difference; i.e., average value of differences in the $1 / 3$ octave bands between the impulsive signal and background noise. This difference is given with the following equation:

$$
w_{a v}=\sum_{i=1}^{N} \Delta w_{i}[\mathrm{~dB}]
$$

where:

$i$ - $i$-th analyzed $1 / 3$ octave band for impulsive signal,

$N$ - total number of $1 / 3$ octave bands,

and difference in the $i$-th $1 / 3$ octave band:

$$
\Delta w_{i}=w_{\operatorname{Im} p, i}-w_{b a c k, i}[\mathrm{~dB}]
$$

where:

$$
\begin{aligned}
w_{\text {Imp }, i}- & \begin{array}{l}
\text { sound pressure level in the } i \text {-th } 1 / 3 \text { octave } \\
\text { band for impulsive signal, }
\end{array} \\
w_{\text {back, } i}- & \text { sound pressure level in the } i \text {-th } 1 / 3 \text { octave } \\
& \text { band for the background noise. }
\end{aligned}
$$

On the basis of the dependencies above, two more descriptors are proposed: spectral centroid (the center of gravity) for the difference between the impulsive signal and background noise $\Delta \bar{x}$, and frequency interval between the center of gravity of the impulsive signal and spectral centroid of ideal impulse (Dirac impulse), $\bar{x}_{\text {diff }}$.
The spectral centroid for the difference between the impulsive signal and background noise is given with the equation:

$$
\Delta \bar{x}=\frac{\sum_{i=1}^{N} \Delta w_{i} x_{i}}{\sum_{i=1}^{N} \Delta w_{i}}[\mathrm{~Hz}]
$$

and regular spectral centroid:

$$
\bar{x}=\frac{\sum_{i=1}^{N} w_{i} x_{i}}{\sum_{i=1}^{N} w_{i}}[\mathrm{~Hz}]
$$

where:

$w_{i}$ - sound pressure level in the $i$-th $1 / 3$ octave band for impulsive signal,

$x_{i}$ - center frequency of the $i$-th $1 / 3$ octave band.

The ideal impulse signal (Dirac impulse) is characterized by a flat spectrum in the entire frequency range. The analytical value of the center of gravity for this signal in the bands from $20 \mathrm{~Hz}$ to $20 \mathrm{kHz}$ is $3132 \mathrm{~Hz}$. Calculating the frequency distance from the spectral centroid of the difference spectra to the center of gravity of the spectrum of ideal impulsive signal can provide information on whether a given signal measured at a certain point might be considered as impulsive, especially in assessing impulses with high-frequency content and measured close to the source:

$$
\bar{x}_{\text {diff }}=\Delta \bar{x}-\bar{x}_{I}[\mathrm{~Hz}]
$$

The values of the descriptors described with Equations (9), (11), and (13) are presented in Table 4. 
Table 4

$w_{a v}, \Delta \bar{x}$ and $\bar{x}_{\text {diff }}$ values for collisions measured in several distances from source

\begin{tabular}{|c|c|c|c|c|}
\hline Collision $\mathbf{N}^{\mathbf{0}}$ & $\begin{array}{c}\text { Distance from } \\
\text { source } \\
{[\mathrm{m}]}\end{array}$ & $\begin{array}{c}w_{a v} \\
{[\mathrm{~dB}]}\end{array}$ & $\begin{array}{l}\Delta \bar{x} \\
{[\mathrm{~Hz}]}\end{array}$ & $\begin{array}{l}\bar{x}_{\text {diff }} \\
{[\mathrm{Hz}]}\end{array}$ \\
\hline \multirow{3}{*}{ Collision 1} & 10 & 45.8 & 3928 & 797 \\
\hline & 120 & 28.9 & 2050 & -1081 \\
\hline & 270 & 11.7 & 1246 & -1885 \\
\hline \multirow{3}{*}{ Collision 2} & 10 & 47.1 & 3828 & 697 \\
\hline & 120 & 25.6 & 2214 & -917 \\
\hline & 270 & 6.7 & 1212 & -1919 \\
\hline \multirow{3}{*}{ Collision 3} & 10 & 50.9 & 3744 & 613 \\
\hline & 120 & 27.1 & 2566 & -565 \\
\hline & 270 & 12.0 & 1991 & -1140 \\
\hline \multirow{3}{*}{ Collision 4} & 10 & 40.0 & 3873 & 742 \\
\hline & 120 & 19.3 & 2310 & -821 \\
\hline & 270 & 7.5 & 1478 & -1653 \\
\hline \multirow{3}{*}{ Collision 5} & 10 & 41.7 & 4029 & 898 \\
\hline & 120 & 24.8 & 2034 & -1097 \\
\hline & 270 & 13.2 & 2098 & -1033 \\
\hline \multirow{3}{*}{ Collision 6} & 10 & 44.5 & 3979 & 848 \\
\hline & 120 & 25.7 & 1958 & -1173 \\
\hline & 270 & 11.9 & 1303 & -1828 \\
\hline
\end{tabular}

For signals measured at a distance of $10 \mathrm{~m}$, large values of $\Delta \bar{x}$ and positive values of $\bar{x}_{\text {diff }}$ indicate the high impulsiveness of the signal with an increased concentration of energy in the higher frequencies. For the other (further) distances, impulsiveness of the events (obtained from spectral descriptors) is not clear; however, due to the attenuation of high frequencies growing with increasing distance, the considered parameters cannot be treated as the recommended determinative in the qualification of impulsive signals. Their usefulness would be much better in close proximity to the source. Average spectral difference $w_{a v}$ decreases as expected with an increasing distance from the source, and its center of gravity shifts towards the low frequencies.

\section{CONCLUSIONS}

In accordance with the criteria (CHABA 1981, 1996, Henderson and Hamernik 1986, Hamernik and Hsueh 1991), all of the signals presented in the article should be treated as impulsive. Within close distance of the sound source, the useful parameters can be impulsiveness $I$ and increase of sound level $\Delta L$. This cannot be said for the difference in exposure levels $L_{C E}-L_{A E}$, which give relatively poor results both at close and long distances from the source. Very promising results for impulse qualification provides Model 2, based on the level difference between $L_{C \max }$ and $L_{A \max }$. This approach is much better in the evaluation of signals generated further distances away from the source; thus, in places where the problem of the qualification of range of impulsiveness is present. Good results in the differentiation of these signals also gives the velocity of impulse rise $V_{L}$.

In the impulsive signal qualification, a useful descriptor that may also be proposed is average spectral difference $w_{a v}$, and as an additional parameter (especially for measurements performed directly at the source), distance from the center of gravity of the difference spectra to the center of gravity of the spectrum of ideal impulsive signal $\bar{x}_{\text {diff }}$. 
This paper does not deal with all aspects of the qualification of impulsive signals, but focuses on assessing the utility of the parameters used by different researchers. This work may also be a starting point in research on new objective parameters based on the physical characteristics of signals, useful in the objective qualification of impulses in regards to their annoyance.

\section{References}

Assessment of community response to high-energy impulsive sounds. Report of Working Group 84. Committee on Hearing, Bioacoustics and Biomechanics (CHABA), National Research Council (National Academy of Science, Washington, DC, 1981) (NTIS ADA110100)

Berry B.F., 1989, Recent advances in the measurement and rating of impulsive noise. Proceedings of 13th ICA, Belgrade, vol. 3, 147-150.

Berry B.F., Bispring R., 1988, CEC joint project on impulse noise: Physical quantification methods. Proceedings of 5th International Congress on Noise as a Public Health Problem, 153-158.

Community response to high-energy impulsive sounds: An assessment of the field since 1981. Committee on Hearing, Bioacoustics and Biomechanics (CHABA), National Research Council (National Academy of Science, Washington, DC, 1996) (NTIS PB 97-124044)
Hamernik R.P., Hsueh K.D., 1991, Impulse noise: some definitions, physical acoustics and other considerations. Journal of the Acoustical Society of America, 90(1), 189-196.

Henderson D., Hamernik R.P., 1986, Impulse noise: Critical review. Journal of the Acoustical Society of America, 80(2), 569-584.

ISO 1996-2:2007. Acoustics. Description, measurement and assessment of environmental noise. Part 2: Determination of environmental noise levels.

ISO 9613-1:1993. Acoustics - Attenuation of sound during propagation outdoors. Part 1: Calculation of the absorption of sound by the atmosphere.

Miedema H.M.E., 2004, Relationship between exposure to multiple noise sources and noise annoyance. Journal of the Acoustical Society of America, 116(2), 949-957.

PN-ISO 10843:2002. Akustyka. Metody opisu i pomiaru pojedynczych impulsów lub serii impulsów.

PN-ISO 1996-1:2003: Acoustics - Description, measurement and assessment of environmental noise. Part 1: Basic quantities and assessment procedures.

PN-ISO 1996-2:1999/A1:2002. Acoustics. Description, measurement and assessment of environmental noise. Part 2: Determination of environmental noise levels (Change A1).

Rozporzadzenie Ministra Środowiska z dnia 30 października 2014 r. w sprawie wymagań $w$ zakresie prowadzenia pomiarów wielkości emisji oraz pomiarów ilości pobieranej wody (Dz.U. 2014 poz. 1542).

Ustawa z dnia 27 kwietnia 2001 r. Prawo ochrony środowiska (Dz.U. $2001 \mathrm{Nr} 62$ poz. 627 z późn. zm.).

Wszołek T., 2015, Korekcja tonalna i impulsowa wskaźników hałasu w kwalifikacji jego źródła [in:] Opieliński K.J., Postępy akustyki 2015, Polskie Towarzystwo Akustyczne, Oddział we Wrocławiu, Wrocław, 413-426. 